\title{
DESCOLEÇÕES E REMIXES NA APRENDIZAGEM DE LÍNGUA INGLESA: UM ESTUDO DE CASO EM UMA ESCOLA PÚBLICA
}

\section{DECOLLECTING AND REMIXINGS IN ENGLISH LANGUAGE LEARNING: A CASE STUDY IN A PUBLIC SCHOOL}

\section{Lesliê Vieira Mulico* Junot de Oliveira Maia}

\section{RESUMO}

Ao concordarmos que a tecnologia pressupõe uma mentalidade caracterizada por uma lógica mais horizontal entre linguagens (GNERRE, 1991 [1986]; OLSON, 1997 [1994]), que todo letramento é metamidiático (LEMKE, 2010) e que as apropriações culturais constituem-se por meio de hibridizações (GARCIA-CANCLINI, 2011[1997]), devemos, como professores de línguas, investigar como tais conceitos podem nos ajudar a melhor compreender o processo de aprendizagem da língua inglesa quando as TDICs entram em cena. Assim, este artigo apresenta uma reflexão acerca do uso de ferramentas de produção e edição de vídeos para o ensino-aprendizagem da língua em uma escola pública federal. Fizemos isso por meio de um estudo de caso baseado em um trailer de filme produzido por um aprendiz como tarefa proposta nas aulas de inglês. Após a avaliação, o professor realizou uma entrevista gravada em vídeo com o aprendiz para que este comentasse seu próprio trabalho. A partir do trailer e da transcrição da entrevista, operacionalizamos algumas reflexões sobre o uso das tecnologias de produção do vídeo por meio dos conceitos de descoleção e remix (GARCIA-CANCLINI, 2011 [1997]), que foram associados aos conceitos de tipologia e topologia (LEMKE, 2010) para analisarmos os efeitos do uso da tecnologia para a aprendizagem da língua inglesa. Esses conceitos possibilitaram um retorno crítico à sequência didática utilizada durante as aulas, e, assim, foi possível observar que o aprendiz dedicou maior esforço às questões topológicas do gênero, o que pode ter sido reflexo da proposta didática realizada na sequência. Se assim o é, sugerimos, então, que devemos buscar práticas de ensino-aprendizagem que promovam uma relação mais horizontal entre os aspectos topológicos e tipológicos da linguagem em uso, especialmente quando nos propomos a lançar mão de práticas em sala de aula que envolvam as TDICs.

Palavras-chave: TDICs; ensino de língua inglesa; letramentos digitais.

\section{ABSTRACT}

Upon agreeing that the use of technology implies a mentality characterized by a more horizontal mindset between languages (GNERRE, 1991 [1986]; OLSON, 1997 [1994]),

\footnotetext{
* Instituto Federal de Educação, Ciência e Tecnologia do Rio de Janeiro, Rio de Janeiro (RJ), Brasil leslie.mulico@ifri.edu.br; Universidade Estadual de Campinas, Campinas (SP), Brasil. junotmaia@ gmail.com
} 
that every literacy is metamediatic, and that cultural appropriations emerge from hybridizations (GARCIA-CANCLINI, 2011[1997]), we thus should, as language teachers, investigate how these concepts may help build an understanding of the process of learning English when the ICDTs (Information and Communication Digital Technologies) come into play. Therefore, this article presents a reflection about the use of video production and edition tools applied to language learning and teaching in a federal public school. This work was carried out based on a case study about a movie trailer designed by a learner to fullfil a task proposed in the English classes. After the evaluation, the teacher invited the learner for a video-recorded interview wherein he was expected to verbally react about his own production. His trailer and the interview transcript enabled reflections about the use of video production technologies, by means concepts such as decollecting and remixing (GARCIA-CANCLINI, 2011[1997]), which were associated with Lemke's concepts of topology and typology so as to analyze the effects of the use of technology for learning English. These concepts paved the way to a critical review of the sequence of activities employed throughout the lessons, and allowed us to observe that the learner undertook greater effort in relation to the topologic features of the genre, which might have been an outcome of the sequence proposed by the teacher. If this is the case, we suggest that we ought to aim for pedagogic practices that promote a more horizontal relationship between the topologic and typological aspects of language in use, particularly when it comes to practices that involve ICDTs.

Keywords: ICDTs; English language teaching; digital literacies.

\section{INTRODUÇÃO}

Em 23 de fevereiro de 1995, o caderno de Informática do jornal Folha de São Paulo veiculava a reportagem "Livros em CD-ROM ensinam brincando"1. Entendendo as tecnologias digitais como recursos essencialmente inovadores e capazes de mobilizar linguagens de forma inédita, o texto chamava atenção para como elas poderiam viabilizar situações de aprendizagem multimídia, as quais facilitariam o contato dos alunos com diversos conteúdos didáticos.

No mesmo ano, em 11 de Abril, outro caderno do mesmo jornal afirmava, com base no Fórum Latino Americano do Uso de Redes Eletrônicas na Educação, organizado pela Organização das Nações Unidas, que uma escola sem computador seria incompleta ${ }^{2}$. O fator crucial para essa incompletude, por sua vez, não residiria exclusivamente no fato de a escola ter ou não um computador em seu espaço físico, mas na maneira como ela conseguiria utilizar as tecnologias digitais para se conectar com outras instituições e com todo o conteúdo disponível na internet, tornando-

\footnotetext{
${ }^{1}$ Informação extraída de http://www1.folha.uol.com.br/fsp/1995/2/15/informatica/14.html. Último acesso em 30 de Dezembro de 2015.

2 Informação extraída de http://www1.folha.uol.com.br/fsp/1995/4/11/cotidiano/48.html. Último acesso em 30 de Dezembro de 2015.
} 
se, desse modo, um nó situado em uma ampla rede de computadores (BARABÁSI, 2009 [2002]).

Anos depois, em setembro de 1998 e ainda na Folha de São Paulo, o jornalista e professor Arnaldo Niskier defendia que os recursos digitais seriam tecnologias de esperança na medida em que permitiriam grande expansão das iniciativas de ensino superior de qualidade em nosso país ${ }^{3}$. Tratava-se, então, de compreender o Ensino a Distância (EaD) como uma possibilidade que, se bem executada, faria o Brasil alcançar consideráveis avanços nos índices relativos ao campo da Educação como um todo e, consequentemente, ampliar seu contingente de mão de obra qualificada para o mercado de trabalho.

Essas três possíveis relações já apontavam, na década de 1990, para a maneira como, de acordo com Braga (2007, p. 182), as dinâmicas de ensino seriam afetadas pelas tecnologias digitais em geral, principalmente por aquelas viabilizadoras de trocas informacionais e consequente acesso à internet. Esse último recurso, de acordo com a autora, é o responsável por viabilizar não só o estabelecimento de comunicações síncronas ou assíncronas a distância, mas também o acesso a um conjunto de conteúdos disponíveis na rede mundial de computadores (a www ou world wide web) e, ainda, a utilização de ferramentas digitais para a construção de textos multi e hipermidiáticos.

Não é de se espantar, desse modo, que, diante da infinidade de recursos inovadores que apresentam, as tecnologias digitais tenham assumido certo papel redentor nos contextos educacionais como um todo, mas, principalmente, na sala de aula (BUCKINGHAM, 2010). A compreensão da internet como banco de dados infinito e fonte consideravelmente diversificada de pesquisa e de situações de aprendizagem, bem como seu potencial multi e hipermídia, capaz de viabilizar tarefas de leitura e de produção distintas daquelas tradicionalmente presentes em sala de aula, sustentam ainda mais a ideia de que a educação estaria sujeita a mudanças paradigmáticas rumo a uma nova realidade.

No entanto, essa ideia de a educação passar por transformações substanciais e necessariamente positivas em função do advento das TDICs - Tecnologias Digitais da Informação e Comunicação - não é unânime. O trabalho de Dwyer et al. (2007), por exemplo, faz uma análise quantitativa detalhada sobre o uso de computador relatado na prova do $\mathrm{SAEB}^{4}$ e conclui que as crianças que nela alcançam melhores resultados, independentemente da classe social à qual pertencem, são aquelas

\footnotetext{
${ }^{3}$ Informação extraída de http://www1.folha.uol.com.br/fsp/opiniao/fz07099809.htm. Último acesso em 30 de Dezembro de 2015.
} 
que dele fazem um "uso leve" (DWYER et al., 2007, p. 1324). Diante disso, o autor critica a falta de estudos empíricos feitos pelos entusiastas da tecnologia que evidenciem e ilustrem o êxito da relação entre recursos digitais e práticas de ensinoaprendizagem, alertando para a perversidade de podermos estar ampliando a dita "desigualdade digital" em função de muita teoria e de pouca análise.

Ora, esse uso inaugural da primeira pessoa do plural neste último período do parágrafo anterior não é gratuito. Autores deste artigo, indexicalizamos e assumimos a posição de pesquisadores e professores que, com base em nossos olhares e experiências, acreditamos nos potenciais de transformação que as TDICs podem assumir nas dinâmicas escolares de ensino-aprendizagem. É com base em nossos percursos, por exemplo, que nos sentimos incomodados com a ausência de evidências qualitativas no trabalho de Dwyer et al. (2007), evidências que poderiam, minimamente, colocar em xeque a confiabilidade das respostas dadas pelos alunos nos longos questionários de avaliações como o SAEB ou o SARESP5. Contudo, acreditamos que o apelo dos autores pela produção de trabalhos empíricos que ilustrem usos adequados dos recursos digitais nas práticas escolares (DWYER et al., 2007, p. 1326) seja, de fato, necessário.

Este texto, portanto, busca atender a essa demanda por experiências concretas. Entendemos, sim, que as tecnologias digitais podem fazer a diferença em múltiplas situações de ensino-aprendizagem e propomos aqui um estudo composto por reflexões teóricas ilustradas por uma atividade prática repleta de complexidades. Especificamente, nosso objetivo é o de refletir qualitativamente sobre a maneira como alunos têm se apropriado de ferramentas digitais para produzirem diferentes gêneros textuais em aulas de língua estrangeira - no caso, inglesa - e, para isso, analisamos um caso específico de uma atividade de produção de vídeo - um trailer - proposta para estudantes de uma escola técnica situada na cidade de Pinheiral, interior do estado do Rio de Janeiro.

${ }^{4}$ O SAEB consiste no Sistema de Avaliação da Educação Básica e é composto por dois processos: a Avaliação Nacional da Educação Básica, focada nas gestões dos sistemas educacionais, e a Avaliação Nacional do Rendimento Escolar, focada em cada unidade e de caráter mais detalhado. Para mais detalhes, consultar o site do INEP (http://portal.inep.gov.br/saeb).

${ }^{5}$ O SARESP consiste no Sistema de Avaliação do Rendimento Escolar do Estado de São Paulo e tem a finalidade de produzir um diagnóstico sobre a situação da escolaridade básica paulista, com vistas a orientar as gestões no monitoramento das políticas voltadas para a melhoria da qualidade educacional. Para mais detalhes, consultar o site da Secretaria da Educação do Estado de São Paulo (http://www.educacao.sp.gov.br/saresp). 


\section{DESCOLEÇÃO E REMIX: UMA REFLEXÃO METAMIDIÁTICA SOBRE APROPRIAÇÕES E LETRAMENTOS}

Um início de conversa em relação à nossa defesa de que as TDICs podem, sim, desestabilizar tradições capazes de engessar certas práticas de ensino-aprendizagem deve levar em consideração que os agentes de sala de aula, professores e alunos, precisam saber lidar com esses recursos tecnológicos. Desse modo, entendemos que tais sujeitos precisem se apropriar produtivamente das tecnologias digitais para realizar tarefas situadas, uma vez que, conforme salientam Braga (2007) e Braga e Vóvio (2015), a simples existência desses aparatos com todas as suas funcionalidades não é capaz de alterar a realidade em seu redor; a diferença, pois, se dá a partir dos usos que são feitos desses recursos.

O processo de apropriação de práticas culturais, em linhas gerais, já foi alvo de reflexão por parte de diferentes teóricos. Michel De Certeau (2012 [1980]), por exemplo, em seu $A$ invenção do cotidiano, propõe uma distinção polarizadora entre insiders e outsiders, estabelecidos hegemônicos e excluídos subjugados, para compreender como se dão os mecanismos de apropriação a partir de uma estrutura binária de poder que opõe estratégias e táticas. Para o autor, ações estratégicas são exclusivamente praticadas pelos grupos empoderados e, por partirem de um lugar de estabilidade e segurança, podem ser constantemente planejadas e (re)pensadas. Ações táticas, por outro lado, ocorrem a partir das práticas daqueles subordinados à força das estruturas de poder e que, por estarem sob constante opressão, precisam buscar espaços que lhes tragam alguma possibilidade de agência.

Garcia-Canclini (2011 [1997]), em seu turno, acredita em uma lógica nãopolarizada para se pensar sobre o mesmo tema. Segundo ele, os sujeitos de diferentes setores sociais se apropriam de práticas culturais a partir de suas reconversões, que podem ser sinteticamente definidas como ações de ressignificação de uma determinada prática cultural em um outro contexto, diferente do original. Essas ações são capazes, por exemplo, de transformar uma costureira em estilista, um arquiteto em marceneiro, um pequeno comerciante em analista de mercado ou, sob uma ótica mais ampla, fazer com que comunidades indígenas explorem os recursos de suas reservas naturais e passem a gerenciar transações econômicas de acordo com a lógica do capitalismo globalizado. São elas, portanto, as responsáveis pela fundamental ocorrência de hibridação entre práticas culturais diversas.

Contudo, essas duas possibilidades de compreensão acerca do processo de apropriação requerem complementações. O modelo certeauniano (2012 [1980]), por exemplo, embora destaque o importante fato de que grupos minoritários 
têm menores possibilidades de ação perante o poder instituído e estabilizado, essencializa e totaliza seus polos com base em agentes incluídos ou excluídos, ignorando o fato de que essas classificações não são estanques, já que poderes estão em constante negociação na sociedade (FOUCAULT, 1979). O modelo de GarciaCanclini (2011 [1997]), por sua vez, é recorrentemente atacado por se embasar em percepções sociais pouco críticas, uma vez que desenvolve as ideias de reconversão e de hibridação sem se preocupar com os fatores que tornam essas práticas muito menos trabalhosas para esferas estabelecidas de poder.

Diante dessas tensões, o trabalho de Maia (2013) buscou levar em consideração as contribuições desses dois recortes teóricos para refletir sobre o

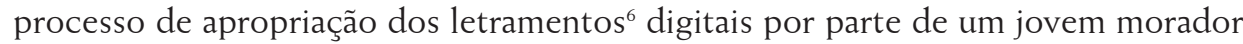
de uma favela carioca na busca pela ampliação de suas chances de participação social. Partindo, pois, da compreensão macroestrutural certeauniana de que os caminhos de ação em sociedade são consideravelmente mais difíceis para sujeitos que estão à sua margem, o autor desenvolveu, a partir dos propósitos de sua pesquisa, as três ações fundamentais constituintes do processo de hibridação tal como proposto por Garcia-Canclini (2011 [1997]): a desterritorialização dos recursos de tecnologias digitais conectadas; a descoleção, por meio do uso desses recursos, dos letramentos tradicionalmente valorizados; e a expansão dos gêneros impuros, baseada no poder de veiculação de informações de redes sociais digitais, caso do Facebook e do Twitter.

Assim, o conceito de descoleção, tal como proposto por Maia (2013), nos parece interessante considerando o nosso propósito de refletir sobre a maneira como os alunos trabalham, a partir das tecnologias digitais, com diferentes gêneros textuais em salas de aula de língua estrangeira. Segundo o autor, a compreensão da escrita como uma coleção se deve, principalmente, ao seu caráter documental e cartorial - como registro, tal como apontada por Chartier (2009 [1998]) -, normativo e regulador, em função de instrumentos de política linguística como os dicionários e as gramáticas (GNERRE, 1991 [1986]), e cognitivamente hierarquizante, como sustentaram Eric Havelock (1963), em seus trabalhos sobre oralidade e escrita na Grécia Antiga, ou David Olson (1997 [1994]), ao discorrer sobre o mundo no papel.

${ }^{6}$ Entendemos, ancorados em Lemke (2010), que letramentos devam ser entendidos como "um conjunto de competências culturais para construir significados sociais reconhecíveis através do uso de tecnologias materiais particulares" (LEMKE, 2010, p. 2), sejam elas "recursos semióticos particulares usados para construir significados (o sistema linguístico vs. o sistema culinário ou de moda) e os artefatos materiais particulares que medeiam esse processo (sons vocais ou sinais escritos vs. comidas, roupas)" (LEMKE, 2010, p. 2). São, em sua essência, sempre sociais, por se constituírem a partir da interação dos sujeitos entre si e com o mundo, e metaforicamente se estabelecem enquanto legiões, uma vez que estabelecem relações transversais entre pessoas, mídias e estratégias de significação. 
As TDICs, contudo, colocam em xeque o "paradigma do texto" (LANKSHEAR; KNOBEL, 2007, p. 13) e trazem à baila outras formas de lidar com a escrita, outros letramentos, já que promovem novas maneiras de construir significação - novas textualizações a partir de novas mídias - capazes de desestabilizar aquilo que, ao longo da história, se constituiu como uma coleção, como estabilidade sustentada pela hegemonia.

A crescente ubiquidade das tecnologias digitais nas práticas sociais contemporâneas (SANTAELLA, 2007) e a ocorrência cada vez mais evidente dessas descoleções, por sua vez, nos permitem assumir a emergência de uma outra ética, não mais "nova", como trataram Lankshear e Knobel (2007). Afinal, o caráter revolucionário das TDICs já é passado (LEANDER, 2008, p. 33) e o novo, nesse caso, deixa de ser tão novo na medida em que esses recursos estão definitivamente presentes na maior parte das realidades, principalmente urbanas, espalhadas pelo mundo. No Brasil, especificamente, o fato de os computadores e outros recursos multimídia terem se popularizado (BRAGA, 2010; HORST, 2011; BRAGA, 2015; BRAGA; VÓVIO, 2015) faz com que ações de descoleção da escrita se tornem ainda mais comuns e evidentes.

Nesse sentido, essa outra ética, componente essencial das ações de descoleção, determina usos transgressores das tecnologias disponíveis e, consequentemente, das escritas nelas e por elas (re)produzidas. Desse modo, ela pressupõe uma outra mentalidade, caracterizada por uma lógica mais horizontal entre linguagens do que aquela característica dos letramentos convencionais (GNERRE, 1991 [1986]; OLSON, 1997 [1994]), típicos do período industrial. As linguagens, portanto, principalmente em função das mídias digitais, assumem um caráter destacadamente híbrido e dinâmico, com textos e gêneros que carregam a instabilidade e a mistura como fatores de sua essência.

Nas últimas décadas, autores como Manovich (2005), Erstad (2008) e Knobel e Lankshear (2008), para citar alguns, têm utilizado o termo remix para se referirem às hibridações linguísticas promovidas a partir dos recursos de diferentes mídias digitais. Embora o termo nos remeta ao campo musical - começou a ser praticado na década de 1970, quando músicas remixadas passaram a ser tocadas pelos Disc Jockeys, os DJs, nas boates espalhadas pelo mundo -, o desenvolvimento das recentes tecnologias digitais no que tange a formas inovadoras de se construir sentidos e a popularização dessas mesmas tecnologias em função de seu barateamento (BRAGA, 2010) permitiram que a ideia de remix passasse a ser utilizada em outros campos. Essa produção de misturas entre linguagens e mídias, por sua vez, passou a integrar também o cotidiano de usuários comuns, não especializados, das TDICs. 
Reconhecendo isso, Manovich (2005) afirma que o termo remix está tão difundido que passou a se referir a qualquer retrabalho sobre um trabalho cultural que já existe.

Entendemos, então, o remix como a

maneira como os usuários colocam em jogo diversas linguagens - sejam elas produzidas por diferentes mídias ou não -, misturando-as a fim de produzir novos e diferente sentidos. De forma mais específica, o remix é determinantemente caracterizado pelo trabalho com a multimodalidade, na medida em que esta representa a combinação de diferentes mídias - e, destarte, de variadas linguagens - em uma nova forma de se expressar, um produto híbrido gerado por múltiplas semioses. (MAIA, 2015, p. 86-87)

Alinhados a essa definição, Hull e Greeno (2006) e Erstad (2008) sustentam a ideia complementar de que os produtos multimodais são aqueles que permitem que os usuários construam sentidos e, desse modo, tornem-se agentes de remixagens. Os ambientes digitais estão, hoje, repletos desses produtos que misturam diferentes semioses: blogs, imagens editadas, memes, montagens de vídeos para diferentes propósitos, gifs, fanfics, trailers caseiros, entre tantos outros gêneros capazes de materializar essa nova mentalidade.

Precisamos, entretanto, ir além do campo da produção e reconhecer também a importância dessa nova mentalidade para a interpretação e o gerenciamento dos sentidos gerados a partir desses produtos híbridos. Afinal, como é de se esperar, seria uma total incoerência se todas essas formas inovadoras de construção de sentidos estivessem sujeitas a interpretações ainda baseadas em modelos passados, mais estritos e formais, característicos da lógica industrial anterior. Por isso, inspirados nas reflexões de Lemke (2010), acreditamos que seja importante registrarmos duas percepções fundamentais acerca de como lidar com os letramentos diante dessa nova mentalidade.

A primeira delas consiste no entendimento de que todo letramento é, em sua natureza, multimidiático. Essa afirmação expõe nossa compreensão de que uma manifestação escrita, quando colocada em prática, instaura-se no presente, moldando-se a ele e agindo sobre ele por meio de uma construção dialética; traz consigo a sua história, na medida em que sua genealogia é inevitavelmente constitutiva de sua própria natureza; e sinaliza comportamentos futuros a seu acontecimento, já que provoca inevitáveis implicações para sua própria constituição e para o contexto em que ocorre. Nesse sentido, letramentos são sempre sociais e são legiões (LEMKE, 2010, p.1), uma vez que são capazes de materializar uma unidade heterogênea, porque híbrida, entre passado, presente e 
futuro, estabelecendo relações transversais entre pessoas, mídias e estratégias de significação.

A segunda, por sua vez, acaba por ser consequência da primeira. Partindo do entendimento de que todo letramento é híbrido por natureza, torna-se essencial que busquemos, como mencionamos anteriormente, caminhos para análise e interpretação que estejam atentos a diferentes formas de se significar. Por isso, concordamos com Lemke (2010) quando ele afirma que precisamos estar mais atentos a aspectos topológicos de construção de sentido, indo além de nossa costumeira atenção a aspectos tipológicos. Considerando, pois, que a língua opera principalmente em função destes últimos aspectos, classificando suas unidades a partir de oposições - categorias mutuamente exclusivas, de modo que uma coisa é o que a outra não é -, é indispensável que não negligenciemos o papel de fatores transversais a essa relação. Os significados topológicos são aqueles, portanto, que, conectados às nossas experiências e contextualizados em função de situações específicas, complementam e multiplicam os sentidos construídos por meio da língua. Lemke (2010) esclarece essa distinção da seguinte maneira:

\begin{abstract}
Estou começando a acreditar que construímos significados fundamentalmente de duas formas complementares: (1) classificando as coisas em categorias mutuamente exclusivas e (2) distinguindo variações de graus (ao invés de variações de tipo) ao longo de vários contínuos de diferença. A língua opera principalmente no primeiro, que chamo de tipológico. A percepção visual e a gesticulação espacial (desenhar, dançar) operam mais no segundo, a forma topológica. Como já argumentei, a construção real do significado geralmente envolve combinações de diferentes modalidades semióticas e também combinações bastante gerais destes dois modos. A semântica das palavras na língua é principalmente categorial ou tipológica em seus princípios, mas as distinções visuais significantes na escrita manuscrita (por exemplo, letras mais escuras ou um pouco mais grossas) ou na caligrafia, ou os efeitos acústicos da fala, um pouco mais alto ou forte, fazem sentido em um espectro contínuo de possibilidades, "topologicamente". (LEMKE, 2010, p. 7)
\end{abstract}

Essas considerações são imprescindíveis para nossos propósitos pois utilizaremos dos conceitos de descoleção e remix para nortear as análises que faremos sobre um $\mathrm{Caso}^{7}$ que, acreditamos, permite reflexões interessantes para se pensar sobre o uso das tecnologias digitais em situações de aprendizagem de língua estrangeira. Tendo isso em mente, passamos agora a uma descrição sobre o

${ }^{7} \mathrm{O}$ estudo de caso, nesse contexto, emerge como estratégia metodológica interessante na medida em que permite enxergar peculiaridades do processo e, ao mesmo tempo, expandir essa visão direcionada para situações mais amplas. É por ser representativo e abrangente que ele se configura como importante estratégia a ser utilizada na pesquisa sobre Linguagens e Tecnologias e, mais especificamente, nas análises e reflexões relativas aos estudos sobre letramentos digitais (MAIA, 2014, p. 606). 
contexto de ensino de língua inglesa no Instituto Federal do Rio de Janeiro, campus Pinheiral ${ }^{8}$, levando em consideração, principalmente, os conceitos e pressupostos que embasaram a atividade de produção anteriormente mencionada de um trailer.

\section{PLANEJANDO A PRÁTICA: CONSIDERAÇÕES SOBRE O ENSINO DE LÍNGUA INGLESA EM UM CONTEXTO ESPECÍFICO}

O ensino da língua inglesa no Instituto Federal do Rio de Janeiro, campus Pinheiral, pauta-se tanto nos pressupostos do Inglês para Fins Específicos ${ }^{9}$ (RAMOS, 2008), buscando atender às demandas das áreas técnicas dos cursos que oferece, quanto nos princípios do Letramento Crítico (LC), a fim de levar o aprendiz à formação para o exercício de uma cidadania ativa, como prescreve a Lei de Diretrizes e Bases (Art. 2\%2015[1996]).

A educação, dever da família e do Estado, inspirada nos princípios de liberdade e nos ideais de solidariedade humana, tem por finalidade o pleno desenvolvimento do educando, seu preparo para o exercício da cidadania e sua qualificação para o trabalho. (LDB, 2015 [1996], p.9)

Assim sendo, na disciplina "Inglês para Fins Específicos", buscamos realizar cruzamentos entre os assuntos relevantes para a formação profissional e para o desenvolvimento do pensamento crítico. Para tal, adotamos o entendimento de LC como "prática educacional que motiva o aprendiz a examinar seu lugar de enunciação e as conexões entre linguagem, poder e conhecimento, a fim de transformar as relações, bem como refletir e agir de forma responsável" (ANDREOTTI, 2007); e como "uso dos meios de comunicação para analisar, criticar, e transformar as normas, os sistemas de regras e as práticas que governam os campos da sociedade da vida quotidiana" (LUKE, 2012).

Para operacionalizar tal entendimento no material didático e nas aulas, lançamos mão dos processos de conbecimentos que constituem a pedagogia da aprendizagem por design proposta por Mary Kalantzis e Bill Cope (2012), organizados em quatro momentos: "prática situada", "instrução", "postura crítica" e "prática transformadora" (tradução de Tilio, 2015, p.200). Tal organização foi proposta pelo Grupo de Nova Londres (GNL) em 1996 como um esforço para operacionalizar os princípios de aprendizagem da teoria sociocultural, cujo cerne é a construção

\footnotetext{
${ }^{8} \mathrm{O}$ campus localiza-se na região sul-fluminense do Rio de Janeiro e oferece cursos técnicos integrados ao Ensino Médio nas áreas de Agropecuária, Agroindústria (EJA), Meio Ambiente e Informática. ${ }^{9}$ Conhecido pela sigla ESP, English for Specific Purposes.
} 
do conhecimento na interação entre os aprendizes e do aprendiz com o mundo. O Quadro 1, a seguir, apresenta uma reinterpretação, promovida por Kalantzis e Cope (2012), desses quatro momentos e tem como objetivo tornar o aprendiz "agente de seu próprio processo de construção de conhecimento"10 $(2012$, p.80).

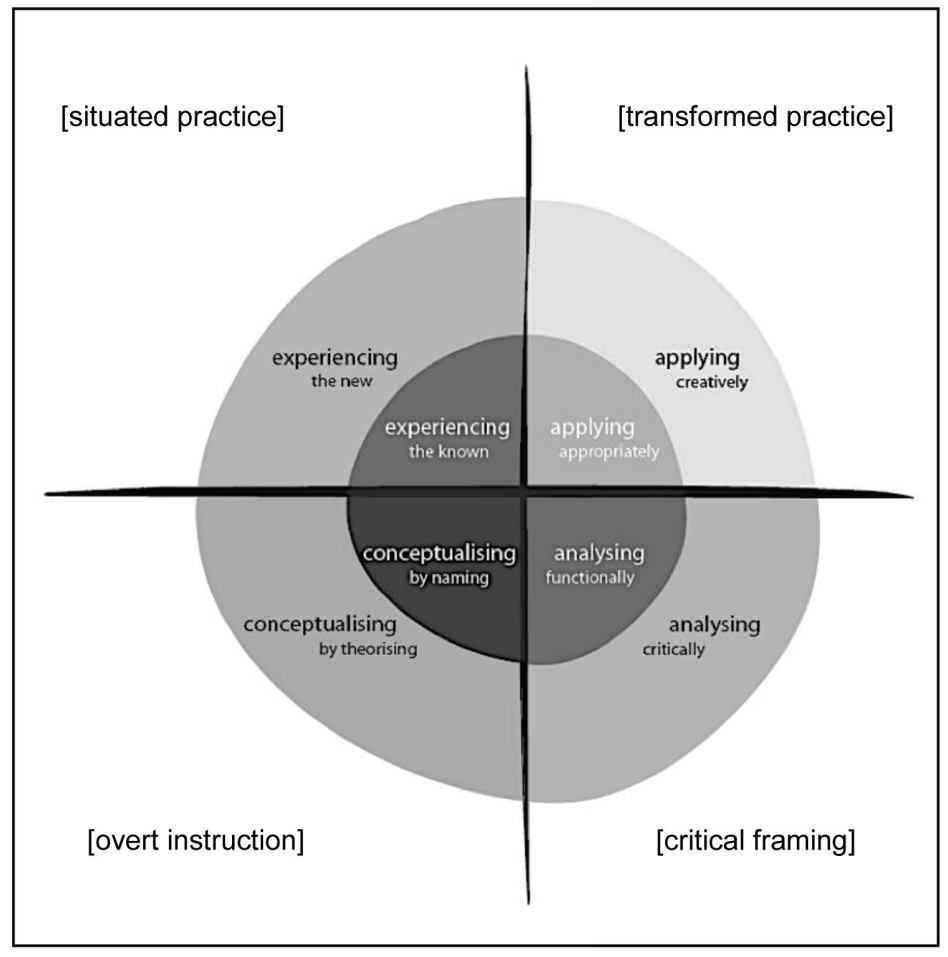

Quadro 1. Processos de conhecimento da pedagogia da aprendizagem por projetos ${ }^{11}$

Definidos como "tipos de atividade que representam uma forma distinta de construir conhecimento e de aprender", esses processos de conbecimento organizam-se de forma a levar o aprendiz a estabelecer relações entre o seu conhecimento concreto (habilidades localizadas no centro do círculo ${ }^{12}$ ) e as competências que demandam

${ }^{10}$ Tradução de nossa inteira responsabilidade. O fragmento completo no original é: "We need instead a literacies pedagogy for active citizenship, centred on highly literate learners as agents in their own knowledge processes and capable of contributing their own ideas as well as negotiating the differences between one community and the next." (KALANTZIS, COPE, 2012, p. 80).

${ }^{11}$ Disponível em: http://newlearningonline.com/learning-by-design/pedagogy. Acesso: 4 dez., 2015.

${ }^{12}$ Da esquerda para a direita, em sentido horário: "experienciar o conhecido", "conceituar nomeando", "analisar funcionalmente" e "colocar em uso apropriadamente" (TILIO, 2015). 
letramentos mais abstratos (localizadas na região periférica ${ }^{13}$ ). Com base no resumo dos processos de conbecimento de Kalantzis e Cope $(2012){ }^{14}$, temos o seguinte panorama, esboçado na Tabela 1:

Tabela 1. Resumo dos processos de conhecimento baseado em Kalantzis e Cope (2012)

\begin{tabular}{|c|c|c|c|}
\hline $\begin{array}{l}\text { PROPOSTA DE PRÁTICA } \\
\text { PEDAGÓGICA DO GNL }\end{array}$ & \multicolumn{2}{|c|}{$\begin{array}{c}\text { REINTERPRETAÇÃO DA PROPOSTA DO GNL POR } \\
\text { KALANTZIS E COPE }(2012)\end{array}$} & $\begin{array}{l}\text { DESCRIÇÃO DAS AÇÕES } \\
\text { PEDAGÓGICAS }\end{array}$ \\
\hline \multirow[b]{2}{*}{ Prática Situada } & \multirow[b]{2}{*}{ EXPERIENCIAR } & o conbecido & $\begin{array}{l}\text { aprendizes refletem sobre suas } \\
\text { próprias experiências familiares, } \\
\text { interesses e perspectivas }\end{array}$ \\
\hline & & o novo & $\begin{array}{l}\text { aprendizes observam ou } \\
\text { participam em algo não familiar; } \\
\text { ficam imersos em novas situações } \\
\text { ou contextos }\end{array}$ \\
\hline \multirow[b]{2}{*}{ Instrução } & \multirow[b]{2}{*}{ CONCEPTUALIZAR } & nomeando & $\begin{array}{l}\text { o grupo pensa em categorias, } \\
\text { aplicam termos que classificam, e } \\
\text { define esses termos }\end{array}$ \\
\hline & & teorizando & $\begin{array}{l}\text { aprendizes fazem generalizações } \\
\text { utilizando os conceitos, } \\
\text { conectam os termos em mapas } \\
\text { conceituais ou teorias }\end{array}$ \\
\hline \multirow[b]{2}{*}{ Postura Crítica } & \multirow[b]{2}{*}{ ANALISAR } & funcionalmente & $\begin{array}{l}\text { aprendizes analisam conexões } \\
\text { lógicas, causa e efeito, estrutura } \\
\text { e função }\end{array}$ \\
\hline & & criticamente & $\begin{array}{l}\text { aprendizes avaliam suas próprias } \\
\text { perspectivas e as de outras } \\
\text { pessoas, assim como seus } \\
\text { interesses e motivos. }\end{array}$ \\
\hline \multirow[b]{2}{*}{$\begin{array}{c}\text { Prática } \\
\text { Transformadora }\end{array}$} & \multirow[b]{2}{*}{$\begin{array}{l}\text { COLOCAR } \\
\text { EM USO }\end{array}$} & apropriadamente & $\begin{array}{l}\text { aprendizes aplicam a nova } \\
\text { aprendizagem em situações reais } \\
\text { do mundo e testam sua validade }\end{array}$ \\
\hline & & criativamente & $\begin{array}{l}\text { aprendizes fazem uma intervenção } \\
\text { inovadora e criativa no mundo, ou } \\
\text { transferem o que aprenderam para } \\
\text { um contexto diferente }\end{array}$ \\
\hline
\end{tabular}

Os autores ressaltam que não há uma sequência fixa de atividades a serem cumpridas, ficando a cargo do professor selecioná-las e misturá-las de acordo com o seu contexto. Tilio (2015) assevera a questão da organização didática com base nesse quadro ratificando, inclusive, que "não existe a obrigatoriedade de cumprir

${ }^{13}$ Idem: "experienciar o novo", "conceituar teorizando", "analisar criticamente" e "colocar em uso criativamente" (TILIO, 2015).

${ }^{14}$ Disponível em: http://newlearningonline.com/learning-by-design/pedagogy. Acesso: 4 dez., 2015. 
sempre todas as etapas, as quais, na prática, nem sempre são tão lineares quanto a teoria" (TILIO, 2015, p.201).

Com base nessa perspectiva, construímos uma sequência didática ${ }^{15}$ que buscou estimular no aprendiz sua capacidade crítica e analítica das múltiplas semioses envolvidas na construção do discurso ${ }^{16}$ sobre o aquecimento global. Isso serviu como meio para levar o aprendiz a ampliar seu repertório de conhecimentos necessários para a produção de um trailer, o que pressupõe inevitavelmente a apropriação de tecnologias de produção e edição de vídeos.

Sendo assim, elaboramos e implementamos, ao longo do primeiro bimestre de 2015, uma unidade didática que permitiu acesso a diversos assuntos e gêneros discursivos ${ }^{17}$ pertencentes ao tema Fenômenos Naturais. Os gêneros wiki, charge, infográfico, pôster publicitário de filme e trailer foram abordados de forma comparativa, reflexiva e problematizadora durante as aulas, em conformidade com os pressupostos do LC, para tratar sobre a diferença entre desastres naturais e ambientais, processos de formação de fenômenos naturais e ambientais, discursos sobre o aquecimento global, descrição e previsão do tempo, problemas ambientais e políticos causados por desastres naturais e impactos ambientais de usinas nucleares. Inusitadamente, finalizamos o percurso com uma discussão sobre gênero e sexualidade com base na canção It's Raining Men, de Paul Jabara e Paul Shafer. A constar, o público-alvo dessa unidade foi uma turma de $3^{\circ}$ ano do Ensino Médio, composta por 26 alunos, do curso técnico em Meio Ambiente.

Esse curso, por sua vez, é uma modalidade integrada ao Ensino Médio com a duração de 3 anos, e tem como objetivo formar profissionais técnicos em nível médio dentro do eixo tecnológico Ambiente e Saúde:

O Técnico em Meio Ambiente tem como funções coletar, armazenar e interpretar informações, dados e documentações ambientais; colaborar na elaboração de laudos, relatórios e estudos ambientais; auxiliar na elaboração, acompanhamento e execução de sistemas de gestão

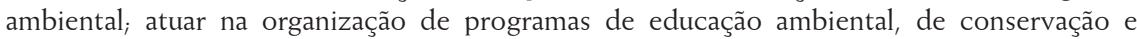
preservação de recursos naturais, de redução, reuso e reciclagem; identificar as intervenções ambientais, analisar suas consequências e operacionalizar a execução de ações para preservação,

${ }_{15}$ Para ter acesso ao material criado, visite: https://drive.google.com/file/d/0B4O_Qz qtn28NnBobjd2cTZVV1E/view? usp= sharing

${ }^{16}$ Discurso é aqui entendido sob a ótica de Halliday (1978) como processo e texto multidimensional, cujo produto final funciona como a realização de ordens semióticas acima da linguagem, com todas as suas inconsistências, contradições e conflitos possíveis que possam existir dentre e entre tais sistemas de ordem superior. Também trazemos, complementarmente, o conceito de discurso de Fairclough (1992, p.63) como "uma forma de prática social [...] um modo de ação, uma forma pela qual as pessoas podem agir no mundo e, especialmente, sobre outras pessoas".

${ }^{17}$ Entendemos gênero discursivo como "tipos relativamente estáveis de enunciado" (BAKHTIN, 2003 [1979]), que organizam a linguagem em formas socialmente reconhecíveis e compartilhadas. 
conservação, otimização, minimização e remediação dos seus efeitos. (Matriz curricular do curso técnico em Meio Ambiente integrado ao Ensino Médio) ${ }^{18}$

Em meio aos assuntos da unidade, decidimos analisar a sequência didática que aborda a questão do aquecimento global por diversos motivos. Primeiramente, trata-se de um assunto amplamente discutido dentro e fora da escola. Além disso, é tema abordado em outras disciplinas do curso, como Geografia e TCG (Topografia, Cartografia e Georreferenciamento), de modo que os alunos têm contato com conteúdos que lhes permitem lidar criticamente com o assunto. Por fim, é o tópico da unidade em que, pela primeira vez, os aprendizes entram formalmente em contato com a análise crítica de textos multimodais em inglês e, por essa via, tomam conhecimento de que a ideia de aquecimento global não é unânime entre os cientistas. Essa experiência, portanto, busca promover a aprendizagem da língua inglesa relacionada, de forma crítica, ao conhecimento técnico também adquirido pelos alunos ao longo de sua trajetória no Ensino Médio, o que reflete o objetivo do IFRJ de formar profissionais qualificados para atuação na comunidade local, no mundo do trabalho e na sociedade como um todo.

A sequência planejada, vale ressaltar, visa a estimular práticas pedagógicas em que o diálogo se estabelece como ferramenta fundamental para a aprendizagem e troca de conhecimento entre professor e alunos, os quais são levados a fazer constantes reflexões sobre o tema e sobre o papel da linguagem na construção de sentidos a ele relacionados. Para encerrá-la, o professor solicita aos aprendizes um produto final necessariamente baseado nos conhecimentos construídos ao longo da sequência. Sendo assim, a fim de chegar a esse produto que finaliza o ciclo de atividades em torno do referido tema, foram propostas as seguintes atividades:

1. EXPERIENCIAR O CONHECIDO E O NOVO: leitura comparativa de duas charges em inglês sobre "aquecimento global", de modo a contextualizar a discussão sobre o tema e abordá-lo de formas distintas: de um lado, como verdade, de outro, como mito;

2.ANALISAR FUNCIONALMENTE E CRITICAMENTE: análise comparativa e crítica dessas charges, tendo em vista os três elementos do contexto de situação de Halliday e Hasan (1989): campo, relações e modo do discurso ${ }^{19}$. Tem

\footnotetext{
${ }^{18}$ Disponível em: http://www.ifrj.edu.br/webfm_send/10122. Acesso em 13 jun., 2016.

${ }^{19}$ De acordo com os pressupostos da Linguística Sistêmico-Funcional (HALLIDAY, HASAN, 1989), o campo do discurso é a natureza da ação social que está acontecendo em um determinado momento da interação em que a linguagem se configura como como componente essencial; as relações do discurso referem-se à natureza dos participantes, status e papéis; e modo do discurso refere-se ao papel que a linguagem está desempenhando na interação.
} 
como objetivo levar o aprendiz a perceber como os constituintes linguísticos das charges mobilizam sentidos na relação com seus elementos imagéticos e como as ideologias presentes em cada charge são socialmente situadas. Como as discussões visam a construir coletivamente uma metalinguagem capaz de sustentar o tipo de análise proposta, a atividade transcorre em língua materna;

3. EXPERIENCIAR O CONHECIDO E ANALISAR FUNCIONALMENTE: leitura de infográfico em inglês para ordenação de informações sobre o processo de formação do efeito estufa. A ideia aqui é proporcionar uma prática de leitura para se refletir sobre organização textual no contexto trabalhado, buscando que o aprendiz tome consciência dos elementos coesivos (principalmente os semânticos) do texto;

4. EXPERIENCIAR O CONHECIDO E O NOVO: leitura de dois pôsteres promocionais em inglês de filmes sobre "aquecimento global" que retratam posicionamentos opostos frente ao tema, como na atividade 1. Considerando que o aprendiz é introduzido a discursos antagônicos acerca do aquecimento global na primeira atividade desta sequência, a leitura dos referidos pôsteres objetiva oportunizar o seu contato com outro gênero discursivo com o intuito de prepará-lo para a análise que segue;

5.ANALISAR FUNCIONALMENTE E CRITICAMENTE: análise contrastiva dos títulos e aspectos visuais dos pôsteres, tendo em vista como o significado se constrói na integração entre texto e imagem. Busca consolidar a construção metalinguística proposta na atividade 2, a qual viabiliza a análise crítica e comparativa dos pôsteres;

6.CONCEPTUALIZAR NOMEANDO E TEORIZANDO: instrução sobre o conceito de intertextualidade e reconhecimento de elementos intertextuais nos pôsteres. Objetiva oferecer um conceito adicional à metalinguagem que viabiliza a análise crítica de textos multimodais (charge e pôster);

7.ANALISAR FUNCIONALMENTE: observação de dois trailers de filmes em inglês sobre aquecimento global: An Inconvenient Trutb ${ }^{20}$ e The Great Global Warming Swindle $e^{21}$, orientada para identificar intertextualidade entre eles no que diz respeito aos seus aspectos visuais, sonoros e linguísticos. Tem como objetivo levar o aprendiz a reconhecer na prática os elementos intertextuais presentes nos trailers;

\footnotetext{
${ }^{20}$ Disponível em: https://www.youtube.com/watch?v=Bu6SE5TYrCM. Acesso em 5 jan., 2016.
}

${ }^{21}$ Disponível em: https://www.youtube.com/watch?v=tLJbPsMmKR8. Acesso em 5 jan., 2016. 
8. ANALISAR CRITICAMENTE: análise global dos efeitos retóricos e das vozes que constroem o argumento principal em cada trailer. Nesta atividade, o objetivo é levar o aprendiz a compreender o conceito de intertextualidade para além do texto escrito, bem como identificar elementos semióticos que ajudam a construir ou desconstruir um clima alarmista nos vídeos analisados;

9.ANALISAR FUNCIONALMENTE E CRITICAMENTE: análise linguística dos textos dos trailers, com o objetivo de identificar a intertextualidade no nível da sentença. Busca-se levar o aprendiz a reconhecer a intertextualidade no nível da linguagem escrita nas legendas dos trailers, bem como identificar os elementos textuais que ajudam a construir ou desconstruir o clima alarmista referido na atividade 8 ;

10. COLOCAR EM USO APROPRIADAMENTE E CRIATIVAMENTE: produzir um trailer em inglês sobre o desastre natural ou ambiental escolhido, que deveria cumprir com as seguintes condições de produção:

k. obedecer à estrutura composicional (BAKHTIN, 2003 [1979]) do gênero trailer de filme;

1. o desastre natural abordado no trailer deve ser o mesmo já trabalhado pelo aprendiz em um projeto anterior que envolveu a transformação de um texto da Wikipédia em um infográfico. No caso, o tema trabalhado foi "Tempestade de Areia" (sandstorm);

m. a narrativa do trailer deve ser condizente com o tema escolhido;

n. o trailer deve possuir um clima alarmista;

o. o uso da língua inglesa deve ser apropriado ao gênero em questão.

Essa tarefa pretende colocar o aprendiz na posição de produtor de discursos, exigindo que ele reflita sobre as análises que construiu ao longo da sequência didática para realizar a tarefa proposta de acordo com todas as especificidades requeridas. Da mesma forma, ele deve levar em conta a relação entre o conteúdo linguístico e semiótico para promover o clima alarmista desejado. Dizendo de outro modo, a produção do gênero trailer nos moldes elencados na atividade 10 requer a confluência entre os usos da língua inglesa, as reflexões críticas sobre discurso e seus efeitos retóricos e os usos de tecnologias digitais para a seleção e produção de semioses na busca pelo resultado desejado. Isso torna a produção desse gênero potencialmente pertinente à aprendizagem da língua inglesa por parte do aprendiz, sem perder de vista os assuntos abordados no curso técnico em que se formou e sem negligenciar o papel inovador das tecnologias digitais nas práticas de sala de aula. 
Assim, como a tarefa final designada para essa sequência envolve competências criativa, organizacional e linguística, levantamos a hipótese de que as TDICs podem contribuir para a aprendizagem da construção de discursos e da língua inglesa (materialidade linguística), na medida em que o aprendiz se envolve na elaboração desse produto. Portanto, buscamos propor reflexões sobre como se dão as apropriações desses recursos de tecnologias digitais em função dessa situação específica de aprendizagem de língua inglesa e como o processo de produção do trailer contribuiu para a tomada de consciência do discurso na construção de significados.

Nossas análises se constroem com base em um caso que traz à tona o trailer e a voz de $\mathrm{Alex}^{22}$, um dos aprendizes que cumpriu satisfatoriamente as exigências estabelecidas para a tarefa. Seu trabalho se destacou em relação às outras produções da turma principalmente por ter entendido que o tipo de trailer esperado era um trailer de filme, e não uma sequência de imagens relacionadas a um determinado fenômeno natural e acompanhada de instruções, como foi o caso da maioria dos trabalhos apresentados.

Alex, 18 anos, um jovem da classe média interiorana do Rio de Janeiro, foi aluno do $3^{\circ}$ ano do Ensino Médio-Técnico em Meio Ambiente em 2015 e adquiriu conhecimento da língua inglesa por meio de músicas, jogos e redes sociais, além das aulas nas escolas onde estudou. Possuía pouca experiência de trocas de bens e serviços (HALLIDAY \& MATTHIESSEN, 2014) com a língua, mas o suficiente para entender frases e palavras isoladas em contextos de produção do cotidiano. Para formar-se técnico em Meio Ambiente, Alex recebeu um total de 162 horas de instrução em língua inglesa distribuídas em 3 anos, período no qual teve contato prioritariamente com propostas pedagógicas para desenvolver habilidades de leitura para a decodificação, interpretação e análise crítica; produção textual de gêneros acadêmicos, híbridos e multimodais; e, em menor escala, competências orais para apresentação pessoal e de seminários específicos.

Após o seu trailer ter sido avaliado em termos de adequação ao gênero, efeito retórico, uso da linguagem e consistência ao tópico, convidamos Alex a participar de uma entrevista gravada em vídeo. O aprendiz, então, teve a oportunidade de rever seu trabalho e fazer comentários sobre seu processo de criação e produção.

Portanto, com base na realização da tarefa, no produto final e na entrevista feita após a avaliação, propomos o estudo do caso em questão. Identificamos no trailer os processos de descoleção e de remix, segundo uma perspectiva metamidiática, para

\footnotetext{
${ }^{22}$ Cumprindo com a cláusula de preservação da identidade original presente no Termo de Livre Adesão assinado pelo aluno, o nome Alex é fictício.
} 
refletirmos, assim, sobre a maneira como Alex se apropria das tecnologias digitais para cumprir com os requisitos da tarefa. Construímos, por conseguinte, relações entre o conteúdo da entrevista com elementos significantes do produto final, articulando uma triangulação (FIGARO, 2014) capaz de trazer maior consistência às nossas afirmações. Além disso, as reflexões suscitadas a partir do acontecimento da atividade permitem problematizar a sequência didática em questão em função dos pressupostos teóricos que a embasam, estabelecendo um paralelo crítico entre o que foi planejado e o que, de fato, ocorreu ao longo de sua realização.

\section{PENSANDO A PRÁTICA: ANALISANDO LINGUAGENS E ESTÉTICAS EM THE SANDSTORM}

A fim de pensar os recursos para construção de sentidos utilizados por Alex, chamamos primeiramente atenção aos elementos presentes nos vídeos trabalhados em sala de aula para contextualizar a realização da atividade. Desse modo, por se tratar de um gênero multimodal, verificamos, nos trailers trabalhados em aula - An Inconvenient Truth e The Great Global Warming Swindle - as seguintes características topológicas principais:

(a) uma trilha sonora instrumental impactante, com ritmo forte e ataques repentinos de certos instrumentos ou de toda a orquestra;

(b) imagens catastróficas em sequência e/ou sobrepostas, cuja dinâmica de transição é sincronizada com o ritmo da trilha;

(c) uso preferencial de fundo preto, que contrasta com a cor da legenda;

(d) falas dos personagens intercaladas ou concomitantes à trilha;

(e) título do filme no final do trailer.

Observamos também as seguintes características tipológicas na legenda do trailer de An Inconvenient Trutb:

(a) uso do futuro will shake e will ever see acompanhado de adjetivos e expressões com polaridade negativa que, ao co-ocorrerem dentro do contexto apresentado, provocam um clima alarmista;

(b) pergunta retórica no passado simples com o verbo betray e sentenças condicionais zero conditional que associam love-planet e love-children com see-film, acentuando tal clima, já que tal condicional constrói uma relação real e imediata entre causa e efeito, instigando e persuadindo o telespectador a agir; 
(c) superlativo the most terrifying e comparativo scarier com polaridade negativa que intensificam o clima alarmista.

A legenda de The Great Global Warming Swindle, provavelmente por promover uma intertextualidade irônica com o filme anterior, lança mão de:

(a) verbos de processo melting, rising e blowing, com polaridade negativa, para fazer referência ao tema abordado;

(b) uma assertiva no presente simples seguida da pergunta retórica scared?, que convoca o telespectador ao diálogo e atinge o clímax alarmista;

(c) resposta à pergunta retórica com o uso do imperativo don't be e de it's not true, no presente simples, que desconstroi o clima alarmista e ironiza o trailer anterior;

(d) falas de estudiosos especialistas no assunto demonstrando a fragilidade do discurso próaquecimento global.

Essas características levantadas a partir dos trailers têm como objetivo levar o aprendiz a perceber como as diferentes semioses são capazes de construir e de desconstruir o discurso alarmista característico do aquecimento global. Sendo assim, todos esses aspectos semióticos e lexicogramaticais foram abordados e discutidos em sala de aula, principalmente porque eles certamente serviriam como modelo no qual o aprendiz poderia se inspirar para realizar sua atividade.

Embora, em seu vídeo, Alex não utilize todos esses elementos de construção de sentido com os quais teve contato durante as atividades realizadas em sala de aula, ele é exitoso ao criar o clima alarmista, com carga de suspense e acréscimo de traços de comicidade, por meio de descoleções e remixes possíveis de serem identificados no seu trailer e com a ajuda de sua entrevista. Entender como essas descoleções e remixes foram feitos é fundamental para verificarmos o papel da apropriação tecnológica na aprendizagem da língua inglesa. Para tal, faremos a descrição do trailer de Alex buscando intersecções com sua entrevista e a teoria apresentada. Assim, convidamos o leitor a acessar o link do trailer de $A_{l e x}{ }^{23}$ e a continuar lendo a descrição e análise que seguem.

O trailer de Alex dura um minuto e vinte e dois segundos (01:22), e apresenta um filme fictício que o aprendiz intitulou The Sandstorm (A Tempestade de Areia). O trailer se sustenta sobre a remixagem entre cenas de ação gravadas na própria escola e sequências de imagem de tempestades de areia pelo mundo, além de legendas, no

\footnotetext{
${ }^{23}$ Disponível em: https://www.youtube.com/watch?v=3uTMht-tPcQ. Acesso em 10 jan. 2016.
} 
decorrer do trailer, com fonte serifada, caixa alta e cor amarela que remetem a filmes de faroeste, e o título do filme, no final, com fonte vermelha Arial em caixa alta, sobrepostas a um fundo preto.

A música que atravessa todo o trailer é O Fortuna, tema de abertura e fechamento da cantata Carmina Burana composta por Carl Orff, entre 1935 e 1936. Na trajetória de Carmina Burana, podemos reconhecer três planos de descoleção e remix. Em um plano histórico, antes de se tornar a música de Orff, a peça emerge de uma coleção híbrida de 254 poemas medievais e textos dramáticos dos séculos XI, XII e XIII, organizados por Johann Andreas Schmeller, a maioria dos quais possuíam teor "obsceno, irreverente e satírico". A compilação apresenta-se híbrida também no plano linguístico, já que as peças foram escritas em latim medieval (principalmente), alemão característico do período entre 1050 e 1350 (middle bigh German) e provençal antigo. No plano musical, é em 1934 que, auxiliado por Michael Hofmann, Orff descoleciona 24 desses poemas e os recoleciona em um livreto, agora em latim, utilizando como critério de escolha temas que abordassem "a inconstância da fortuna e da riqueza, a natureza efêmera da vida, a alegria do retorno da primavera, e os prazeres e perigos de beber, a gula, jogos de azar e luxúria", como consta em verbete da Wikipédia ${ }^{24}$.

Mesmo com temática dita impura, Carmina Burana estabelece-se como parte do repertório clássico e torna-se música de prestígio dentro do cenário cultural erudito. No trailer de Alex, é, mais uma vez, descolecionada - da música erudita (letramento valorizado) a um trailer de filme, caseiro, amador - e ressignificada como "música de suspense com ação", como aponta Alex neste fragmento da entrevista.

07:14 (Alex) Isso aí é O Fortuna que é essa música, for-tu-na-te, sei lá, não lembro, essa música aí caiu perfeitamente a gente colocou ela assim, ??? colocou ela, a gente precisava de uma música assim de suspense com ação, coisa assim, a gente colocou, caiu perfeitamente assim no negócio lá nas cenas e tal até quando falou eh ehh "Ob my God!" tava... o tempo parou da música assim na hora, e foi perfeito assim, muito maneiro.

07:42 (Professor) Mas isso foi proposital ou veio na hora?

07:45 (Alex) Não, veio na hora, então, a gente colocou o...... a música no tempo do vídeo e caiu perfeitamente! Tudo isso,

${ }^{24}$ Disponível em: https://en.wikipedia.org/wiki/Carmina_Burana e https://en.wikipedia.org/wiki/ Carmina_Burana_(Orff). Acesso em: 10 de jan., 2016. 
entendeu? Pô ficou perfeito! Ficou perfeito! A gente achou, foi muito... muita sorte, não sei.

07:59 (Professor) E essa música é de algum seriado que você já conhecia?

08:01 (Alex) Essa música é... eu acho bem famosa, eu conheço pô isso pra você ver todo mundo aqui deve ter algum trailer alguma coisa assim

08:07 (Professor) Mas como é que você achou essa música?

08:08 (Alex) A gente procurou na internet, procurou no YouTube músicas assim e... e essa música já é tava um pouco na minha cabeça só que eu não lembrava o nome dela.

08:16 (Professor) Pois é, não, ehhh por isso que eu to te perguntando.

08:18 (Alex) Ela fica na minha cabeça, eh ela fica, eu acho ela muito famosa essa música, ela_muito famosa mesmo. Eu gosto muito também.

08:23 (Professor) Mas o que que você digitou no YouTube?

08:25 (Alex) Ehhh "músicas de suspense..." procuramos trailers, desses antigos assim que tem um jeito de falar assim com essa voz grave e tal..., ehhh a gente procurou "música de ação" e escreveu ass_procurando procurando, e aí a gente encontrou essa música

Ao definir O Fortuna como música de "suspense com ação", Alex demonstra empreender maior atenção aos aspectos topológicos da composição, visto que a temática de seu trailer se distancia tipologicamente da temática original do poema da música. Assim, o aprendiz encontra nos ataques de tímpanos e pratos, nos ataques dos instrumentos de cordas e metais, e na melodia do canto polifônico em staccato as pistas indexicais que ativam suas memórias de ação e suspense construídas no contato com outros filmes, como podemos depreender da sua afirmação em 08:01 da entrevista. Como veremos, a trilha sonora que Alex utiliza é base para os remixes e descoleções em seu trailer, inclusive quando o "erro" e o "acaso" são tratados como constitutivos do processo de produção.

Em termos de "acaso", identificamos, no primeiro trecho da entrevista destacado acima, a satisfação de Alex ao demonstrar como a música e as cenas se harmonizam "perfeitamente", especialmente quando menciona a pausa na música que destaca a interjeição $\mathrm{Ob}$ my God! em 00:23. Até chegar a esse ponto, o trailer constrói o clima alarmista da seguinte forma: 
(00:00) entra um personagem adolescente e uniformizado correndo na pista de saída do colégio em direção à câmera;

(00:02) inicia-se a música;

(00:03) entra uma tela preta com a primeira legenda lida por uma voz grave e gutural ${ }_{i}$

(00:04) o personagem reaparece correndo, de cabeça para baixo, câmera lateral e imagem semidesfocada.

Essa sequência que intercala a corrida do personagem em diferentes ângulos com as demais legendas se estende até 00:17, quando começa a entrar, no ritmo da música, uma sequência de cinco fotos de diferentes tempestades de areia até 00:22. Sob nosso ponto de vista teórico, podemos sugerir que o clima alarmista requerido pela tarefa constrói-se entre as descoleções e remixes empregados na música, textos e imagens que Alex hibridiza, muito provavelmente a partir do seu conhecimento prévio, bibliotecário - letramento informático, nos termos de Lemke (2010) -, acerca do gênero em questão. Isso, pensamos, possibilita que o "acaso" aja favoravelmente ao cumprimento da tarefa na medida em que a produção de Alex obedece à estrutura composicional do gênero.

Em termos de aprendizagem, Alex demonstra entender quais seleções de filme, imagem, música e texto são potentes para construir discursivamente o clima alarmista proposto. Recorre, assim, a uma trilha sonora impactante, imagens catastróficas sincronizadas no ritmo da trilha, uso de fundo de tela preto contrastando com o amarelo da legenda e falas concomitantes à trilha e intercaladas às imagens, conforme desenvolvido em aula, objetivado na atividade 7 (cf. seção 2 deste artigo). Nesse sentido, Alex também empreende intertextualidade com os trailers da sequência didática, já que lança mão dos mesmos recursos topológicos. No que tange aos aspectos tipológicos, ele demonstra observância ao uso do verbo de processo rising, com polaridade negativa, de pergunta retórica e do uso de imperativo, conforme descritos nas atividades 8 e 9 (cf. seção 2). Tal fato sugere que, para realizar os remixes e as hibridações para a produção do trailer, Alex lança mão de competência analítica funcional e crítica (KALANTZIS e COPE, 2012) - também desenvolvida nas atividades 2 e 5 (cf. seção 2) - para consolidar o discurso alarmista no gênero proposto.

Assim como o "acaso" pode favorecer a qualidade da realização do trailer, considerando que o aprendiz seja capaz de reconhecer quais elementos devem ser descolecionados e como encontrar suas ressignificações, algo semelhante pode ocorrer com o que Alex, na entrevista, entende e nomeia como "erro". 
O "erro" também é incorporado ao trailer sem comprometer a estrutura composicional do gênero. Entretanto, Alex emprega o termo "erro" para falar sobre três momentos de sua produção, o que nos ajuda a pensar sobre como a apropriação das TDICs em questão pode propiciar a aprendizagem da língua inglesa na interação com os elementos topológicos e tipológicos do trailer. Sendo assim, vejamos o que Alex fala sobre o erro na entrevista.

(legenda: In the summer)

00:22 (Alex) Essa essa parte eu tinha filmado só que eu errei o lado da câmera e quando foi pra eu botar pra editar eu tive que colocar de cabeça pra baixo. Mas acho que dá uma ideia bacana (risos) ficou esquisito, mas é eu achei bom colocar.

No primeiro fragmento, Alex comenta que errou o posicionamento da câmera entre 0:04 e 0:06 segundos do trailer, dizendo que a cena ocorreu inesperadamente, fora do que havia planejado. Isso, contudo, não o impede de utilizá-la, já que reconhece, ao menos intuitivamente, que há ganhos retóricos na construção discursiva do trailer, ainda que não soubesse identificá-los conscientemente. Sendo assim, Alex classifica a instabilidade da mão do cinegrafista que desfoca parcialmente a imagem e a cena de ação de cabeça para baixo, elementos que promovem certa tensão ao trailer, como algo que "dá uma ideia bacana", fora do comum ("esquisito, mas"), e "bom". Dessa forma, o aprendiz avalia o inesperado, o equívoco, como "erro", diferentemente do que ocorre no segundo fragmento.

(legenda: Do you ready?)

03:24 (Alex) Ess_Essa frase tá errada, você falou.

03:27 (Professor) É. Sim, enfim, mas descobriu qual é a certa já?

03:30 (Alex) Não descobri.

03:30 (Professor) Vai descobrir!

03:31 (Alex) Ai, droga! (risos) Tenho que descobrir (risos).

No segundo fragmento, Alex refere-se à frase da legenda *Do you ready? e lembra que cometeu um "erro". Lembra, porque recebeu feedback do professor, porém não consegue identificá-lo, pois revela que, apesar de o professor ter apontado que há um uso gramatical inapropriado na pergunta, ainda desconhece a forma apropriada: Are you ready?. O "erro" aqui não se trata de um equívoco ou algo inesperado para o aprendiz, tanto que a legenda aparece no trailer em dois momentos (0:07 e 0:46 segundos), e Alex só toma ciência de que há um uso inapropriado após 
o comentário do professor. Isso nos permite sugerir, por um lado, que a apropriação da tecnologia de gravação e edição de vídeo por Alex contribuiu para uma tomada de consciência voltada aos aspectos topológicos (elementos semióticos do trailer e seus mecanismos de produção) do gênero, e, por outro, que o aprendiz pode se beneficiar de práticas de feedback com enfoque nos aspectos tipológicos (uso linguístico gramatical e pragmaticamente apropriado para o gênero). Nesse sentido, sob ambas as óticas, o uso das TDICs no processo de ensino-aprendizagem mostra-se produtivo, já que elas podem se tornar ferramentas de uma pedagogia autoavaliativa, na qual o professor leva o aprendiz a pesquisar e refletir sobre sua apropriação linguística dentro de seu próprio universo criativo.

O terceiro momento que Alex classifica como erro ao falar de seu trailer encontra-se descrito no seguinte fragmento.

(fala do personagem: Ready? Do you ready?)

04:11 (Alex) Eh teve uns erro aí essa não era pra ser a fala.

04:13 (Professor) Ah não?

04:14 (Alex) Não aí colocou ess_aí tev_teve um problema lá no vídeo lá que a gente... não era pra ser essa fala que eu falei agora. Era pra ser outra.

(fala do personagem: $\mathrm{Ob}$ man! Ob fuck! $\mathrm{Ob}$, abh, ob shit!)

04:23 (Professor) Essa?

04:23 (Alex) É. Não era. (olhando pra baixo, sem graça)

04:25 (Professor) Mas por que que você acha que não cabia aí?

04:28 (Alex) É por que errou errei o jeito de falar, errei as coisas e tal, e não era essa... essa era a primeira vez que eu falei. Aí eu falei "não essa não foi boa" aí eu fui tentar de novo. Aí a que eu tentei de novo parece que... não deu, não saiu, aí colocou no YouTube e num não deu pra ir e não tem mais o arquivo.

Referindo-se aos 0:50 segundos do trailer, Alex prenuncia e ratifica que a fala que segue não deveria ter sido utilizada, e que, sendo assim, havia cometido um "erro". O professor-entrevistador, então, parece perceber que, desde o início desse comentário, o aprendiz não se referia às perguntas Ready? ou Do you ready?, articuladas na voz gutural do narrador, mas às que seguem: $O b$ man! $O b$ fuck! $O b$, abh, ob shit!. Então, pede para aprofundar o comentário a fim de entender melhor por que Alex havia classificado tal fala como "erro", já que é uma opção discursiva disponível para a estrutura composicional do gênero trailer nos moldes requeridos. Alex, por sua vez, revela, primeiramente, que havia gravado outra fala, mas teve "um 
problema" com o vídeo que inviabilizou a edição do material que havia escolhido. Em seguida, aponta que "errou" a prosódia ("errei o jeito de falar") e que aquela fala havia sido a primeira gravação, que foi prontamente incorporada ao trailer e logo publicada no YouTube. Tais comentários corroboram nossa observação acerca de a atenção de Alex estar, neste ponto, mais voltada aos aspectos da produção do trailer do que do uso da linguagem, já que o aprendiz parece concentrar como foco de sua preocupação os problemas na construção do vídeo, as ferramentas de edição e os elementos semióticos do trailer, deixando as questões relacionadas ao uso da linguagem em segundo plano. Essa situação reitera a sugestão que já propusemos ao destacarmos o papel das TDICs de apontar ao professor o tipo de feedback mais apropriado, se voltado aos aspectos topológicos ou aos tipológicos. No caso de Alex, a ação sobre o último surge como necessária.

Ao longo da entrevista, Alex fala sobre outras descoleções e remixes de que lança mão para produzir seu trailer. Um deles é a apropriação linguística da legenda Winter is coming no trailer de Game of Thrones's, que é remixada para The sand is coming entre 0:35 e 0:40 segundos, proferida vagarosa e pausadamente com voz gutural e em fundo preto. $\mathrm{O}$ fragmento The sand... ocorre juntamente com a imagens dos olhos arregalados do personagem, em zoom, que contribui com o efeito alarmista; e ...is coming co-ocorre com seus lábios, também em zoom, os quais, supostamente, estão proferindo o fragmento. Destacamos o advérbio "supostamente" porque, no trailer, há certa assincronia entre o que é dito e o movimento dos lábios, e, além disso, no final desse segmento, o personagem projeta sua língua para fora e, em seguida, esboça um sorriso. Esses elementos imprimem comicidade ao trailer, como apontado no início desta seção.

Dessa forma, apesar de ter trazido à tona a referência a Game of Thrones na entrevista, a estética do produto de Alex distancia-se da utilizada no trailer desse seriado. Em contrapartida, por conta desses traços de comicidade e da qualidade de produção do vídeo - que conta com "falta de recursos" (tecnológicos), como ele mesmo revela no início da entrevista -, o aprendiz aproxima sua produção de uma estética cinematográfica chamada trash, como o próprio comenta.

05:54 (Professor) Aham, mas geralmente você pega essas influências
de onde? Você falou Game of Thrones, que mais?
05:58 (Alex) Eu pego tudo de... de filme... de filme, filme, seriado,
essas coisas que eu gosto de ver, entendeu? ... Até de filme
trasb e tal

\footnotetext{
${ }^{25}$ Disponível em: https://www.youtube.com/watch?v=qSqnO8iGz9o. Acesso em: 13 dez., 2015.
} 


\begin{tabular}{|c|c|}
\hline 06:07 & (Professor) Ah você gosta de filme trash? \\
\hline 06:08 & (Alex) Gosto de filme trash (rindo) \\
\hline $06: 10$ & (Professor) Qual filme? Me dá um exemplo aí. \\
\hline $06: 12$ & $\begin{array}{l}\text { (Alex) Poxa, tem o... Piranhas, tem o Tomates Assassinos. É } \\
\text { tudo ruim (rindo). Eu sou muito fã, mas acho engraçado. }\end{array}$ \\
\hline $06: 20$ & (Professor) Isso aí_é o que? Década de 80 é isso? \\
\hline $06: 22$ & $\begin{array}{l}\text { (Alex) Os filmes trashes? Eles existem até hoje. Só que... ele... } \\
\text { eles dão humor muito..., não sei explicar, hmm ehhh muito... } \\
\text { ácido assim e acho que é } \underline{\text { bom, num é né bom, bom mas é }}\end{array}$ \\
\hline 06:44 & $\begin{array}{l}\text { engraçado, acho engraçado. } \\
\text { (Professor) Uhum, aqueles filmes que são caseiros né, que o } \\
\text { pessoal faz... }\end{array}$ \\
\hline $06: 47$ & $\begin{array}{l}\text { (Alex) Eh, não tem uns filmes assim, mas. Já viu Sharkinator, } \\
\text { nunca ouviu falar não desses filmes? Tá perd_é horrível! } \\
\text { (risos). É horrível, mas é... eu acho legalzinho. }\end{array}$ \\
\hline 57 & (Professor) É ruim mas é bom né? \\
\hline $06: 58$ & (Alex) Mas é bonzinho. Também não é aquilo, mas bacana. \\
\hline 07:01 & (Professor) Dá pra rir né? \\
\hline 07:02 & Dá pra rir. \\
\hline
\end{tabular}

O trecho destacado mostra que, ao tentar entender melhor o que seria "filme trash", o professor-entrevistador leva Alex a fornecer pistas indexicais para definir tal estética. Primeiramente, é importante notar que, lançando mão do concessivo "até de filme trash" (05:58), Alex deixa subentendido que se trata de um gênero impuro. Essa ideia é corroborada quando utiliza termos como "ruim", "horrível", "num é bom, bom" e "também não é aquilo" para explicar a estética, co-ocorrendo juntamente com as adversativas "mas é engraçado", "mas é... acho legalzinho", "Mas é bonzinho" e "mas bacana". Assim sendo, podemos observar que ser "ruim" e ser "engraçado" são duas características básicas, na visão de Alex, para que o filme seja classificado como trash. Tal concepção se coaduna com aquelas apresentadas em sítios, blogs e fóruns sobre o tema, tais como Wikipédia, The Dark One Podtrash, Cineclick, Megaphone ${ }^{26}$ e Yahoo! Respostas ${ }^{27}$, alguns dos quais citamos a seguir.

A definição de Filme Trash, em geral, trata-se de um filme

\footnotetext{
${ }^{26}$ Disponível em: http://www.portalmegaphone.com.br/press/cinema-a-estetica-do-trash/. Acesso em 14 jan., 2016.

27 Disponível em: https://br.answers.yahoo.com/question/index? qid=20090113111640AAlkAwZ. Acesso em 14 jan., 2016.
} 
tecnicamente mal feito (propositadamente ou não) mas que é considerado bom. A estética cinematográfica Trash pode ser usada em qualquer gênero de filme ou vídeo, mas é mais usada no Terror. Costuma-se considerar Trash todo filme de Terror que ao invés de causar medo ou tensão, é engraçado. (Disponível em: https://pt.wikipedia.org/wiki/Filme trash. Acesso em 14 jan., 2016.)

A definição de filme trash ainda é muito discutível, mas em geral trata-se de um filme mal feito propositalmente ou não. Muitas vezes são associados a filmes de terror, mas um filme (ou vídeo) trash é uma estética que pode ser usada em qualquer gênero. (Disponível em: http://td1p.com/trash-por-definicao/. Acesso em 14 jan., 2016.)

Nos primórdios do gênero, filme trash era aquele de baixo orçamento, geralmente associado ao terror, que acabava gerando risos ao invés de assustar devido à estética fake exagerada. Com o passar do tempo, até as produções com verba sobrando passaram a apostar nessa linha. (Disponível em: http://www.cineclick.com.br/noticias/conheca-mais-sobre-oestranho-e-exagerado-mundo-dos-filmes-trash. Acesso em 14 jan., 2016.)

Essas definições ajudam-nos a entender melhor que, quando Alex se refere ao filme trash como "ruim", ele está apontado para a qualidade da produção, e que o "engraçado" aponta para o exagero, o "fake". Ambos são identificáveis no trailer, não somente na assincronia entre lábios e texto aos 0:38 segundos, como também nos amplos movimentos de braços na corrida do personagem no início, nas suas expressões faciais aos 0:14 segundos, no céu azul em plano de fundo aos 0:23 segundos em um trailer sobre a tempestade de areia, no sorriso que o personagem esboça em 1:01 ao tentar representar que está sendo atacado pela tempestade, entre outros.

Assim, se a composição Carmina Burana - O Fortuna fornece a base melódicorítmica para que o trailer possua um clima alarmista, a estética trash viabiliza os traços de humor. Dessa forma, ao descolecionar um gênero hegemonicamente aceito e outro dito impuro, remixando-os, Alex dá espaço para que as demais descoleções e remixes emerjam em seu trailer: a pista de saída do colégio, as imagens de tempestade de areia ao redor do mundo, a voz grave e gutural, a legenda com fonte amarela 
que remete aos filmes de faroeste, as apropriações linguísticas de seriados, a tentativa de reprodução dos efeitos especiais, entre outras que podem ter passadas despercebidas nessa análise.

Tendo em vista, pois, as questões apontadas acerca dos processos de produção do trailer de Alex e da aprendizagem da língua inglesa, consideramos importante pensar nas implicações de suas ações para o ensino da língua inglesa. Faremos isso refletindo criticamente sobre a sequência didática utilizada ao passo em que levantaremos questões sobre o papel do professor de línguas frente às TDICs.

\section{CONSIDERAÇÕES FINAIS}

Os caminhos trilhados por Alex para a realização da atividade nos conduzem, por fim, a questionamentos interessantes, capazes de suscitar algumas considerações finais. Desse modo, o que podemos refletir, afinal, sobre a sequência didática utilizada, o professor de inglês (da escola pública, em particular) e o ensinoaprendizagem da língua na apropriação das TDICs a partir do trailer de Alex?

Primeiramente, é necessário lembrar que o jovem é um aluno com pouca experiência com a língua inglesa, capaz de compreender frases e palavras isoladas em contextos cotidianos, especialmente aqueles oriundos de sites, seriados e músicas. Apesar de suas limitações, a incumbência de produzir um determinado gênero a partir do uso das TDICs promoveu agenciamentos que o levaram a acionar sua rede de contatos para conseguir dominar certos recursos de tecnologia cujos letramentos não eram de seu domínio prévio. Nesse sentido, o aprendiz revela, logo no início da entrevista, que pediu ajuda a um amigo para fazer suas gravações e editá-las: põe em prática, desse modo, uma mentalidade colaborativa de trabalho, estabelecendo parcerias a fim de viabilizar a realização da tarefa que lhe foi requisitada.

Podemos também dizer que a produção do trailer converteu-se em benefício para o desenvolvimento da postura crítica de Alex perante um determinado tipo de discurso. Assim, ao assumir o papel de produtor de um trailer alarmista por meio do uso de tecnologias digitais, o aprendiz, colocando em prática seus letramentos, teve a oportunidade de tomar consciência sobre como a linguagem e suas múltiplas semioses se organizam para produzir o efeito retórico que foi designado.

Além disso, essa mesma tarefa permitiu o empreendimento da competência criativa de Alex, que realizou descoleções e remixes dos elementos que compõem seu repertório cultural, os quais foram construídos nas suas experiências sociais e no contato com diversas manifestações culturais. Para descolecioná-las, Alex lançou 
mão das ferramentas de busca e download disponíveis na internet; para remixá-las, os programas de produção e edição de vídeo tiveram papel central, assim como um DJ necessita de pick-ups e samplers para remixar, samplear e executar suas músicas. Dizendo de outro modo, foi por meio das TDICs que Alex foi capaz de executar o que havia pensado para o trailer, produzindo um gênero que consiste em hibridações de diversas linguagens, como imagens, sons e frases de impacto.

E como se constitui a aprendizagem da língua inglesa nesse cenário? Como foi possível notar, a tarefa e o uso das TDICs possibilitaram a Alex ser agente de sua própria aprendizagem, tanto das ferramentas tecnológicas quanto dos elementos linguísticos em si. O aprendiz incorporou criativamente alguns dos usos linguísticos abordados na sequência didática, lançando mão de verbos de processo e de perguntas retóricas, atendendo à estrutura composicional do gênero em questão. Esses recursos foram utilizados criativamente na tarefa ${ }_{i}$ dessa forma, o aprendiz não somente atendeu aos requisitos nela contidos, como também adicionou elementos de humor ao seu produto final.

$\mathrm{Na}$ entrevista, Alex nos informa que o seu trailer foi um tanto quanto diferente do idealizado durante a fase de preparação, já que dependia de uma ferramenta mais avançada de edição da qual não dispunha, o que o levou a substituí-la pelo programa Windows Movie Maker, o qual considerou mais simples. Como o aprendiz, desde o início da entrevista, problematizou essa questão da tecnologia necessária para o cumprimento da tarefa e, além disso, concentrou suas observações mais nas questões técnicas da produção do que na questão do uso da linguagem para aquele gênero, podemos inferir que os aspectos topológicos se sobrepuseram aos tipológicos. Em outras palavras, ao enveredar-se pela produção de um trailer alarmista, notamos que seu foco maior recaiu sobre os efeitos de som e transição de imagem, deixando em segundo plano os elementos linguísticos do gênero em questão.

Se por um lado isto serve de termômetro para o professor decidir como intervir via feedback para oportunizar a aprendizagem dos elementos linguísticos abordados na sequência; por outro, acreditamos também que isso possa ter ocorrido porque trailers costumam apresentar um forte traço retórico de persuasão através da imagem. Entretanto, não deixamos de considerar a contribuição da sequência didática para tal desequilíbrio.

A sequência didática proposta para essa tarefa (cf. seção 2) totaliza 18 momentos organizados de acordo com a sistematização de Kalantzis e Cope (2012). Mais especificamente, há 9 propostas de análise, 5 de promoção de experiências, 2 de conceptualização e 2 de uso. Percebemos, de forma geral, que há certo desequilíbrio entre as propostas da sequência, pois privilegia a análise em 
detrimento da conceptualização e a experiência em detrimento do uso, elementos que deveriam estar mais integrados ao longo das atividades.

Se extrapolarmos os conceitos de topologia e tipologia de Lemke (2010) para refletirmos sobre a sequência proposta, podemos sugerir que, ao privilegiar a leitura e análise de textos multimodais, os aspectos topológicos foram privilegiados. Chamamos de aspectos topológicos da sequência didática, no caso, atividades como leitura comparativa e crítica de charges e pôsteres, nas quais os aspectos visuais, muitas vezes, ganham mais atenção na análise dos alunos; a observação comparativa e crítica de trailers, em que a intertextualidade visual e sonora é mais prontamente percebida do que a linguística, já que se trata de um gênero em movimento; e, podemos dizer, ainda, o empreendimento do ato de interpretar dos alunos sobre os elementos suprassegmentais para o reconhecimento de ideologias em cada texto proposto.

Assim, para alunos com a experiência com a língua inglesa semelhante à de Alex, é possível que houvesse um maior equilíbrio entre os aspectos topológicos e tipológicos no trailer se os momentos de análise e conceptualização tipológica fossem ampliados ou mais valorizados na sequência didática antes de designar a tarefa. Afirmamos isso por entendermos que estar atento aos fatores topológicos significa equilibrá-los com outros, tipológicos, em função dos requisitos da tarefa, e não simplesmente lançar mão de um recurso em detrimento do outro. Afinal, fosse este o caso, estaríamos apostando em um binarismo que só faz alterar a natureza do erro: não se atentar a fatores topológicos é tão equivocado quanto preocupar-se somente com eles.

No que diz respeito às contribuições da experiência relatada neste artigo para o ensino de línguas para fins específicos no IFRJ Pinheiral, o caso de Alex sugere que a convergência entre o uso de assuntos relacionados à área técnica e a produção criativa de gêneros de circulação do cotidiano, como o trailer, pode contribuir para uma formação técnica para o trabalho que caminhe de mãos dadas com a formação cidadã, como quer a LDB (2015 [1996], p.9). Além disso, o trailer de Alex exemplifica uma ação pedagógica com vistas à integração e à interdisciplinaridade, sem pressupor a colonização de um determinado tipo de saber pelo outro. Trata-se, portanto, de uma prática pedagógica para a construção da autonomia, exercida por Alex ao longo de todo o seu processo criativo de produção e que será necessária em todos os momentos de sua vida pessoal e profissional.

Finalmente, voltamos a frisar que não estamos propondo uma relação pedagógica de causa e efeito, mas sim refletindo em retrospectiva sobre a sequência didática utilizada e a prática pedagógica para o ensino de línguas a partir do caso 
de Alex. Acreditamos que refletir sobre a própria prática é parte essencial da ação do professor, que deve transbordar o papel de simples instrutor em uma relação assimétrica entre professor-aluno, e passar a desempenhar a função de organizador e orientador da aprendizagem. Uma das maneiras que a reflexão ativa permite sugerir é que devemos buscar práticas de ensino-aprendizagem para a autonomia e que promovam uma relação mais horizontal entre os aspectos topológicos e tipológicos da linguagem em uso, especialmente quando nos propomos a lançar mão de práticas em sala de aula que envolvam as TDICs.

\section{REFERÊNCIAS BIBLIOGRÁFICAS}

ANDREOTTI, V. An ethical engagement with the other: Spivak's ideas on education. In.: SOUZA, LMTM, ANDREOTTI, V. (Eds). Critical Literacy: Theories and Practices. UK: CSSGJ, University of Nottingham, v.1, n.1, p.69-79, 2007.

BARABÁSI, A. Linked: a nova ciência dos networks. São Paulo: Editora Leopardo, 2009 (2002).

BAKHTIN, M. Estética da criação verbal. Tradução de Maria E. G. Pereira. São Paulo: Martins Fontes, 2003 [1979].

BRAGA, D. B. Prática letradas digitais: considerações sobre possibilidades de ensino e de reflexão social crítica. In: ARAUJO, J. C. Internet e Ensino - novos gêneros, outros desafios. Rio de Janeiro: Lucerna, 2007.

BRAGA, D. B. Tecnologia e participação social no processo de produção e consumo de bens culturais: novas possibilidades trazidas pelas práticas letradas digitais mediadas pela internet. Trabalhos em Linguística Aplicada, V. 49, N. 2. Campinas: IEL/UNICAMP, 2010.

BRAGA, D. B. (Org.) Tecnologias digitais da informação e comunicação e participação social. São Paulo: Cortez, 2015.

BRAGA, D. B.; VÓVIO, C. Uso de tecnologia e participação em letramentos digitais em contextos de desigualdade. In: BRAGA, D. B. (Org.) Tecnologias digitais da informação e comunicação e participação social. São Paulo: Cortez, 2015.

BRASIL, Lei de Diretrizes e Bases. Lei no 9.394/96, de 20 de dezembro de 1996.

BUCKINGHAM, D. Cultura digital, educação midiática e o lugar da escolarização. Educação \& Realidade, V. 35, N.3. 2010. Disponível em: http://seer.ufrgs.br/educacaoerealidade/ article/view/13077. Acesso em: 26 jan. 2016.

CHARTIER, R. A aventura do livro: do leitor ao navegador. Tradução de Reginaldo Carmello Corrêa de Moraes. $1^{a}$ reimpressão. São Paulo: Imprensa Oficial do Estado de São Paulo, Editora UNESP, 2009 [1998].

DE CERTEAU, M. A invenção do cotidiano - Artes de fazer. $18^{a}$ Ed. Tradução de Ephraim Ferreira Alves. Petrópolis: Vozes, 2012 (1980). 
DWYER, T.; WAINER, J.; DUTRA, R. S.; COVIC, A.; MAGALHÃES, V. B.; FERREIRA, L. R. R.; PIMENTA, V. A.; CLAUDIO, K. Desvendando mitos: os computadores e o desempenho no sistema escolar. Educação e Sociedade, V. 28, N. 101. Campinas: CEDES, 2007.

ERSTAD, O. Trajectories of remixing: digital literacies, media production, and schooling. In: LANKSHEAR, C.; KNOBEL, M. (Eds.) Digital literacies: concepts, policies and practices. New York: Peter Lang, 2008, p. 177-202

FAIRCLOUGH, N. Discourse and social change. Cambridge: Polity Press, 1992.

FIGARO, R. A triangulação metodológica em pesquisas sobre a Comunicação no mundo do trabalho. Fronteiras - estudos midiáticos, V. 16, N. 2. São Leopoldo: Unisinos, 2014.

FOUCAULT, M. Microfísica do poder. $8^{a}$ Ed. Tradução de Roberto Machado. Rio de Janeiro: Graal, 1979.

GARCIA-CANCLINI, N. Culturas bíbridas: estratégias para entrar e sair da modernidade, $4^{\mathrm{a}}$ Ed, 5a Reimpr. São Paulo: Editora da Universidade de São Paulo, 2011 (1997).

GNERRE, M. Linguagem, escrita e poder. 3 ed. São Paulo: Martins Fontes, 1991 (1986).

HALLIDAY, M. A. K. Language as social semiotic: the social interpretation of language and meaning. London: Edward Arnold, 1978.

HALLIDAY, M. A. K.; HASAN, R. Language, context and text: aspects of language in a social-semiotic perspective. Oxford: Oxford University Press, 1989.

HALLIDAY, M. A. K.; MATHIESSEN, M. I. M. Halliday's introduction to functional grammar. 4a edição. London and New York: Routledge, 2014.

HAVELOCK, E. Preface to Plato. Cambridge: Harvard University Press, 1963.

HORST, H. Free, social and inclusive: appropriation and resistance of new media technologies in Brazil. International Journal of Communication, V. 5. 2011. Disponivel em: http://ijoc.org/index.php/ijoc/article/download/699/531. Acesso em: 26 jan. 2016.

HULL, G.; GREENO, J. Identity and agency in nonschool and school worlds. In: BEKERMAN, Z.; BURBULES, N.; SILBERMAN-KELLER, D. (Eds.) Learning in places: the informal education reader. New York: Peter Lang, 2006, p. 77-98.

KALANTZIS, M.; COPE, B. Literacies. Cambridge: Cambridge University Press, 2012.

KNOBEL, M.; LANKSHEAR, C. Remix: the art and craft of endless hybridization. Journal of Adolescent \& Adult Literacy, V. 52, N. 1. 2008. Disponível em: https://elearning.psu.edu/ drupal6/.../remix article.pdf. Acesso em: 26 jan. 2016.

LANKSHEAR. C. ${ }_{i}$ KNOBEL, M. Sampling "the New" in New Literacies. In: A New Literacies Sampler; New literacies and digital epistemologies; V. 29. New York: Peter Lang, 2007.

LEANDER, K. M. Toward a connective ethnography of online/offline literacy networks. In: COIRO, J.; KNOBEL, M.; LANKSHEAR, C.; LEU, D. J. (Eds.) The Handbook of Research in New Literacies. New York: Taylor \& Francis Group, 2008, pp. 33-66.

LEMKE, J. Letramento Metamidiático: transformando significados e mídias. Trabalhos em Linguística Aplicada, Vol. 49(2). Campinas: IEL/UNICAMP, 2010, p. 455-479. 
LUKE, A. Critical literacy: foundational notes. In.: AVILA, J; PANDYA J.Z. (Eds.) Theory into Practice. London: Routledge, v.51, s/n, p.4-11, 2012. Disponível em: http:// dx.doi.org/10.1080/00405841.2012.636324. Acesso em: 27 jan. 2015.

MAIA, J. O. Apropriação dos letramentos digitais para participação social mais ampla: um estudo de caso. Dissertação de mestrado. Campinas: Universidade Estadual de Campinas, 2013.

MAIA, J. O. Autoria em meio digital: reflexões sobre agência e autoridade. In: LINS, H.A.M. (org). Tecnologias, linguagens e letramentos: sociedade, educação e subjetividade. Campinas, SP: Edições Leitura Crítica; Associação de Leitura do Brasil - ALB, 2015.

MAIA, J. O. O estudo de caso nas pesquisas de e-gov: a relevância de um olhar qualitativo na pesquisa em Linguagens e Tecnologias. Linguagem \& Ensino, V. 17, N. 3. Pelotas: UCPel, 2014, pp. 603-626.

MANOVICH, L. Remixability and Modularity. 2005. Disponível em: http://manovich.net/ index.php/projects/remixability-and-modularity. Acesso em: 11 jun. 2013.

OLSON, D. R. O mundo no papel: as implicações conceituais e cognitivas da leitura e da escrita. Tradução de Sérgio Bath. São Paulo: Ática, 1997 (1994).

RAMOS, R. C. G. ESP in Brazil: history, new trends and challenges. In: KRZANOWSKI, M. (Ed.). ESP and EAP in Developing and in Least Developing Countries. IATEFL, 2008. p. 68-83.

SANTAELLA, L. Linguagens líquidas na era da mobilidade. São Paulo: Paulus, 2007.

TILIO, R. (Org.). Voices 1. São Paulo: Editora Moderna, 2015.

Recebido: 31/01/2016

Aceito: 05/07/2016 